
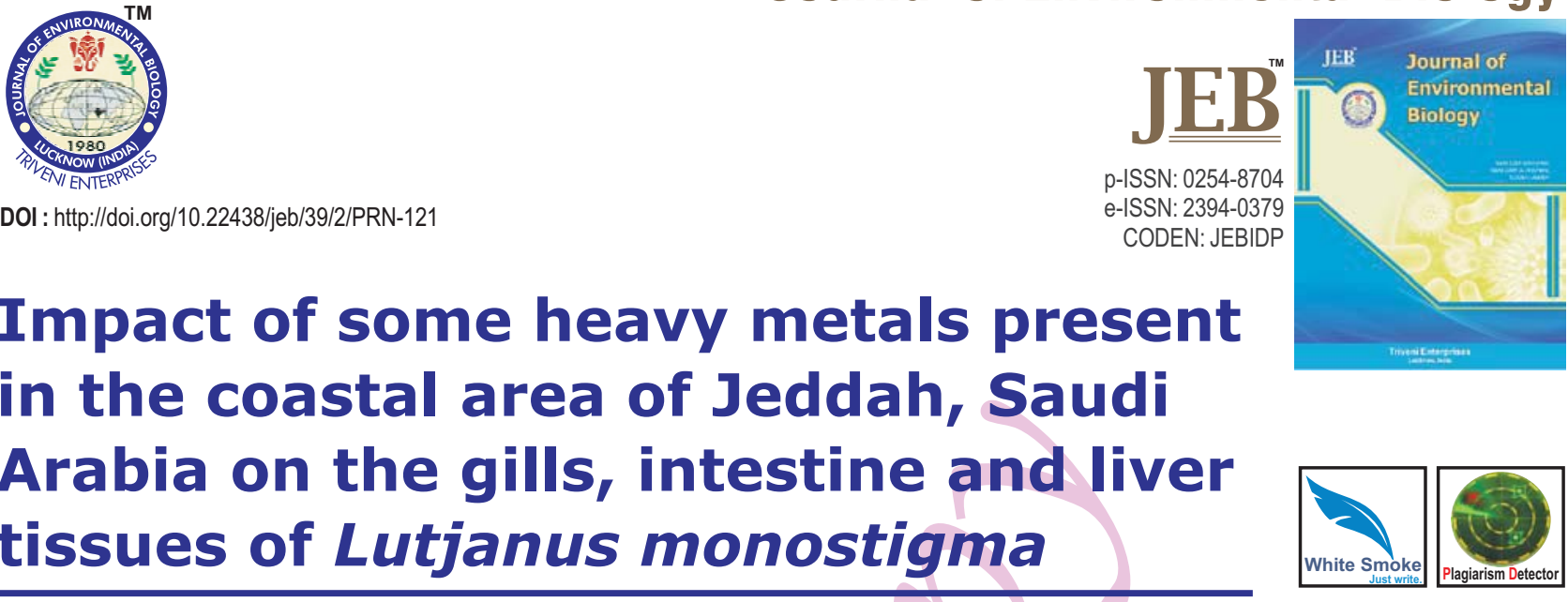

\title{
Impact of some heavy metals present in the coastal area of Jeddah, Saudi Arabia on the gills, intestine and liver tissues of Lutjanus monostigma
}

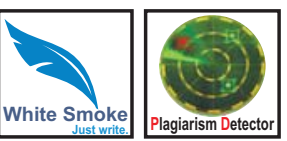

\section{Authors Info}

\section{EL Jawaher A. Bin Dohaish \\ Biological Science, Deparment Faculty of Sciences, Al Faisaliah King Abdulaziz University, Jeddah, 21589, Saudi Arabia}

*Corresponding Author Email : Dr.aljawaher@gmail.com

Key words

Aquatic pollution

Heavy metals

Histological variations

Lutijanus monostigma

\section{Publication Info}

Paper received : 01.02 .2016

Revised received : 25.07 .2016

Re-revised received: 09.10 .2017

Accepted : 15.11.2017

\section{Abstract}

Aim : Jeddah city is one of the most industrialized cities in the Kingdom of Saudi Arabia. In the present study, concentration of heavy metals iron, lead and nickel was estimated in the sediments and surface water of Red Sea, Jeddah and histological variations in the fish Lutjanus monostigma.

Methodology : Water, sediment and fish samples of Lutjanus. monostigma fish from the Red Sea were collected from three random locations along coastal fishing regions shoreline $500 \mathrm{~m}$, foreshore $2500 \mathrm{~m}$ and offshore $5000 \mathrm{~m}$ seaward. The concentration of heavy metals, iron, nickel and lead in water and sediments were estimated by atomic absorption spectrophotometer. Histological variation in gills, liver and intestine of fish Lutjanus monostigma were also studied .

Results : The perusal of data revealed high concentration of $\mathrm{Fe}, \mathrm{Pb}$ and $\mathrm{Ni}$ in the sediments than in water samples. Several histological variations like hypertrophy, separation of respiratory lamellae, proliferation of chloride cells, increased mucous secretions, necrotic pillar cells, swelling and fusion of secondary lamellae as well as migration of epithelial cells of the lamellae with complete dissolution of blood sinusoids were observed in the gill tissues. The intestinal variation showed villi heterogeneity, increased mucous cells, vacuolar degenerations and separation of mucosal epithelial layer of intestinal villus, submucosal hyperplasia and disintegration of muscular layer with lymphocytic infiltration. Hepatocytes exhibited ballooning degeneration, nuclei pyknosis and karyolysis, sinusoidal collapse, lipid droplet accumulation and lymphocytic infiltration.

Interpretation : The present study concludes that sediments and coastal water of Red Sea, Jeddah is polluted with heavy

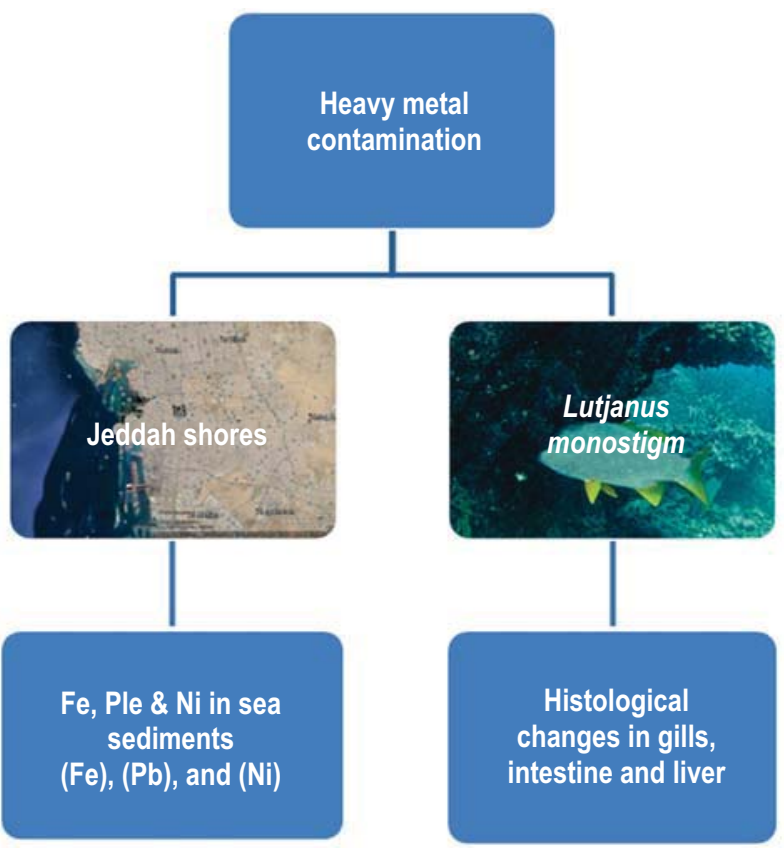
metals which might induce histological variations in the tissues of L. monostigma. 


\section{Introduction}

Fish is a vital source of food for millions of people worldwide. In 2008 , about $81 \%$ of estimated world fish production was used as human food (FAO, 2010). Potential accumulation of heavy metals in fish is a matter of concern for the health of the consumers (Elnabris et al., 2013). Previous studies have reported that pollutants of both natural and anthropogenic origins are known to induce variations of different magnitudes in the physiological and biochemical status of animals (Vosyliene and Kazlauskiene,1999; Ezemonye and Ogbomida,2010). Therefore, biomarkers act as environmental monitor with the advantage of providing quantitative response as valuable information on ecological relevance, as well as on the adverse acute/chronic effects caused by water pollution (De la Torre et al., 2005). Fish acts as bioindicators for evaluating the toxic effect of the compounds on the aquatic ecosystem (Ervnest, 2004). Jeddah city is one of industrialized cities in the Kingdom of Saudi Arabia; in addition, it has a high population density particularly pilgrims who come during pilgrimage season.

Therefore, the coastal water of the study area receives different pollutants like untreated domestic sewage, industrial wastes and fish remnants from Jeddah Center Fish Market (Albannqlh). In addition, the presence of barrier reef limits the water exchange with the open, sea which increases the pollution (Bin Dohaish et al., 2004; El-Ghazaly et al., 2006). Heavy metals form an important group of water contaminants, because of their high toxicity and persistence in aquatic ecosystems (Oscar et al., 1996) and exhibit eliciting toxicological effects at target organisms (Ali and Abdel-Satar, 2005). In response to agricultural, sewage and industrial pollutants, several histological variations have been observed in the gills, liver, kidneys and gonads of Oreochromis niloticus, Tilapia zillii and Synodoniis schall fish (Mohamed, 2003) in response to agricultural, sewage and industrial pollutants. Bin Dohaish et al. (2004) reported the toxic effect of heavy metals in water and sediments from the Red Sea, Jeddah, Saudi Arabia on the kidney and blood profile of rabbit fish Siganus rivulatus. However, there is little knowledge about the current potential accumulation of heavy metals in the Red Sea coastal water which is important for the health of fish consumers. In view of the above, the present study was undertaken to determine the level of heavy metals in the Red Sea coastal water of Jeddah, Saudi Arabia. In addition, the effect of these heavy metals on histological aspects of gill, intestine and liver of commercial fish Lutijanus monostigma was also studied.

\section{Materials and Methods}

Study area : The study area is located at the Red Sea coastal zone at the middle part of Jeddah city, situated between longitudes $21^{\circ} 29^{\prime}-21^{\circ} 30^{\prime} \mathrm{N}$ and latitudes $39^{\circ} 10^{\prime}-39^{\circ} 11^{\prime} \mathrm{E}$. The sampling sites were divided into three random locations along coastal fishing regions shoreline $500 \mathrm{~m}$ (site 1), foreshore $2500 \mathrm{~m}$ (site 2) and offshore $5000 \mathrm{~m}$ seaward (site 3 ), respectively. The water depth between shore and coral reefs ranged from $2 \mathrm{~m}$ and 25 meters, and behind the coral the depth increased to about $35 \mathrm{~m}$.

\section{Sampling area}

Fish samples : The fish samples of Lutijanus monostigma were collected from the different sites. One hundred and sixty three fish were collected from study sites twice a month for six months by trammel and impounding (trap) nets which were fixed at random distances along the study area.

Water and sediments samples : Water samples were collected monthly for determining the heavy metal concentration using Ruttner water sampling bottle of one litre capacity. Sediment samples was carried out monthly by a stainless steel grab sampler "Kerman Barge Grab Sampler" (El-Ghazaly et al., 2006). The concentration of heavy metals, (iron, nickel and lead) in water and sediments of study sites were estimated with atomic absorption spectrophotometer (model AA-7000, 2014, Shimadzu Japan) following the standard protocol of APHA (2012).

Morphometric examination of fish : Morphometric parameters were calculated as total weight $(\mathrm{g})$, total length $(\mathrm{cm})$ and Fulton's condition factor (K) as pe-Htun-Han (1978) equation.

Histological examination for fish : Fish samples were dissected for histological examination of gills, liver and intestine al tissues. These tissues were fixed in Bouin's solution for 24hrs and then washed $\mathrm{h}$ in running tap water and dehydrated in a graded series of alcohol, cleared in xylene and embedded in paraffin wax. Approximately, $2 \mu$ section of tissues were cut using a rotary microtome and stained with hematoxylin and eosin. The prepared sections were examined using Zeiss compound microscope (Hadi and Alwan, 2012) for histological variation .

Statistical analysis : The data were expressed as mean value \pm SD, using SPSS version 16. To compare mean between the groups, student's t- test was used.

\section{Results and Discussion}

A significant decrease in fish number, total weight and length was observed in fish Lutijanus monostigma However, concentrations of $\mathrm{Fe}, \mathrm{Pb}$ and $\mathrm{Ni}$ in sediments were higher than in water as expressed in Table 1 and 2. The concentration of heavy metals in the surface water of three sites was found in the following order : $\mathrm{Fe}>\mathrm{Ni}>\mathrm{Pb}$, whereas in surface sediments $\mathrm{Fe}$ was found in highest concentration followed by $\mathrm{Ni}$ and $\mathrm{Pb}$ at site 1 and $\mathrm{Pb}$ and Ni at site 2 and 3 , respectively.

High levels of heavy metal $\mathrm{Fe}, \mathrm{Pb}$ and $\mathrm{Ni}$ reported in the study areas may be due to increased sewage discharge, industrial effluents decomposing organic matter and oxidation of chemical constituents, further due to. Chemical stability, heavy metals tends to accumulate in surface water, sediment and 
tissues of different organisms (Younis et al., 2013; Mahmoud et al.,2014 ). High concentration of metals in water can retard growth of fish causing possible alterations in fish size. The fish growth can be affected due to the presence of heavy metals in water, especially at early stages such as hatching time, larval development and juvenile growth as they are more sensitive than at mature stages. In addition, Canli and Atli (2003) reported that the fish size parameter (length and weight) of fish indicates accumulation of heavy metals the tissues. Widianarko et al. (2000) observed a significant reducion in lead concentrations with the increase in size, whereas concentrations of copper and zinc did not depend on body weight of Poecilia reticulate. In contrast, Nussey et al. (2000) showed negative relationships between fish sizes and $\mathrm{Cr}, \mathrm{Mn}, \mathrm{Ni}, \mathrm{Pb}$ levels in the tissues of fish Labeo umbratus. It was found that correlations between heavy metals in organs and individual condition factors of fish samples have opposite trends to those among the size of fish (Farkas and Specziár, 2003. Condition factor reveal information about the specific condition. In the present study, lowest value of condition factor 'K' of Lutijanus monostigma was recorded as 0.535 at site3, whereas the highest was recorded as 1.424 and 1.420 from site 1 and 2, respectively (Table.3). Similar findings were reported by Araneda et al. (2008) who observed that condition factor greater than one is an bioindicator to good fitness of fish. Datta et al. (2013) proved that the condition factor (K) reflects general fish condition, physical and biological alterations by interaction among feeding conditions, parasitic infections and physiological factors. In agreement with the present study, Chandra and Jhan (2010) reported K value of Channa punctata in the range of 1.051.89. Several histological alterations were observed in the gills, intestine and liver, tissues of $L$. monostigma. The normal histological gills structure of $L$. monostigma fish have (Fig. 1A) four gill arches on each side of the buccal cavity. Each arch is composed of primary lamellae with numerous gill filaments employed in ionic regulation. It is also sided by two rows of secondary lamellae that run perpendicular to each filament required for gaseous exchange. Secondary gill lamellae consist of cells which were contractile and separated the blood capillary paths. Chloride cells were identified as large epithelial cells with light cytoplasm, usually present at the base of the lamellae. Similar histological structure in L. monostigma was reported by Peebuaa et al. (2006) (Fig.1D) lamellar swelling and lamellar

Table 3 : Body weight, length, liver weight and Condition factor of the fish Lutijanus monostigma collected from different sites

\begin{tabular}{lllll}
\hline $\begin{array}{l}\text { Sites } \\
\text { Jeddah fish market }\end{array}$ & $\begin{array}{l}\text { Total weight } \\
\mathbf{( g )}\end{array}$ & $\begin{array}{l}\text { Total lengh } \\
\mathbf{( c m}\end{array}$ & $\begin{array}{l}\text { Liver } \\
\text { weight }\end{array}$ & $\begin{array}{l}\text { Condition } \\
\text { Factor }(\mathbf{K})\end{array}$ \\
\hline Site1 : shoreline $(500 \mathrm{~m})$ & $93.875 \pm 39.93$ & $17.528 \pm 1.9463$ & $1.266 \pm 0.471 \mathrm{NS}$ & $1.424 \pm 0.160$ \\
Site2 : foreshore $(2500)$ & $83.378 \pm 31.55$ & $18.719 \pm 2.060$ & $0.958 \pm 0.425$ & $1.420 \pm 0.174$ \\
Site3 : offshore $(5000 \mathrm{~m})$ & $51.260 \pm 3.597^{* *}$ & $15.556 \pm 1.102^{*}$ & $0.912 \pm 0.205$ & $0.535 \pm 0.097^{* *}$ \\
\hline
\end{tabular}

$P>0.05$ not significant; $P<0.01^{* *} \& 0.001^{* * *}$ highly significant; $N S=$ not significant

Table 1 : Concentration of heavy metals $\left(\mu I^{-1}\right.$ wet wt.) in the surface water of study sites

\begin{tabular}{llll}
\hline Sites : & & Heavy metals & $\mathrm{Ni}$ \\
\cline { 2 - 4 } Jeddah fish market & $\mathrm{Fe}$ & $\mathrm{Pb}$ & $25.27 \pm 0.030^{*}$ \\
\hline site 1 : shoreline $(500 \mathrm{~m})$ & $144.3 \pm 7.07$ & $8.435 \pm 0.65^{*}$ & $24.015 \pm 0.045$ \\
Site 2 : foreshore $(2500 \mathrm{~m})$ & $155.9 \pm 10.09^{* *}$ & $12.27 \pm 1.35$ & $18.03 \pm 0.48^{*}$ \\
site 3 : offshore $(5000 \mathrm{~m})$ & $148.6 \pm 4.18$ & $14.965 \pm 2.45^{*}$ & 1.03 \\
\hline
\end{tabular}

Values are mean of five fish \pm samples $S D ; P>0.05$ not significant; $P<0.01^{*} \& 0.001^{* *}$ highly significant

Table 2 : Concentration of heavy metals $\left(\mu \mathrm{g}^{-1}\right.$ wet $\mathrm{wt}$.) in the surface sediments of study sites

\begin{tabular}{llll}
\hline Sites : & & Heavy metals & \\
\cline { 2 - 4 } Jeddah fish market & Fe & $\mathrm{Pb}$ & $\mathrm{Ni}$ \\
\hline site 1 : shoreline $(500 \mathrm{~m})$ & $1751.3 \pm 108.57^{*}$ & $74.33 \pm 5.65^{*}$ & $77.56 \pm 3.33^{* *}$ \\
Site 2 : foreshore $(2500 \mathrm{~m})$ & $1520.7 \pm 45.24$ & $93.22 \pm 5.11$ & $54.59 \pm 4.08^{*}$ \\
site 3 : offshore $(5000 \mathrm{~m})$ & $1844.6 \pm 41.22^{* *}$ & $87.88 \pm 4.66$ & $67.98 \pm 3.25$ \\
\hline
\end{tabular}

Values are mean of five fish samples $\pm S D ; P>0.05$ not significant; $P<0.01^{*} \& 0.001^{* *}$ highly significant 


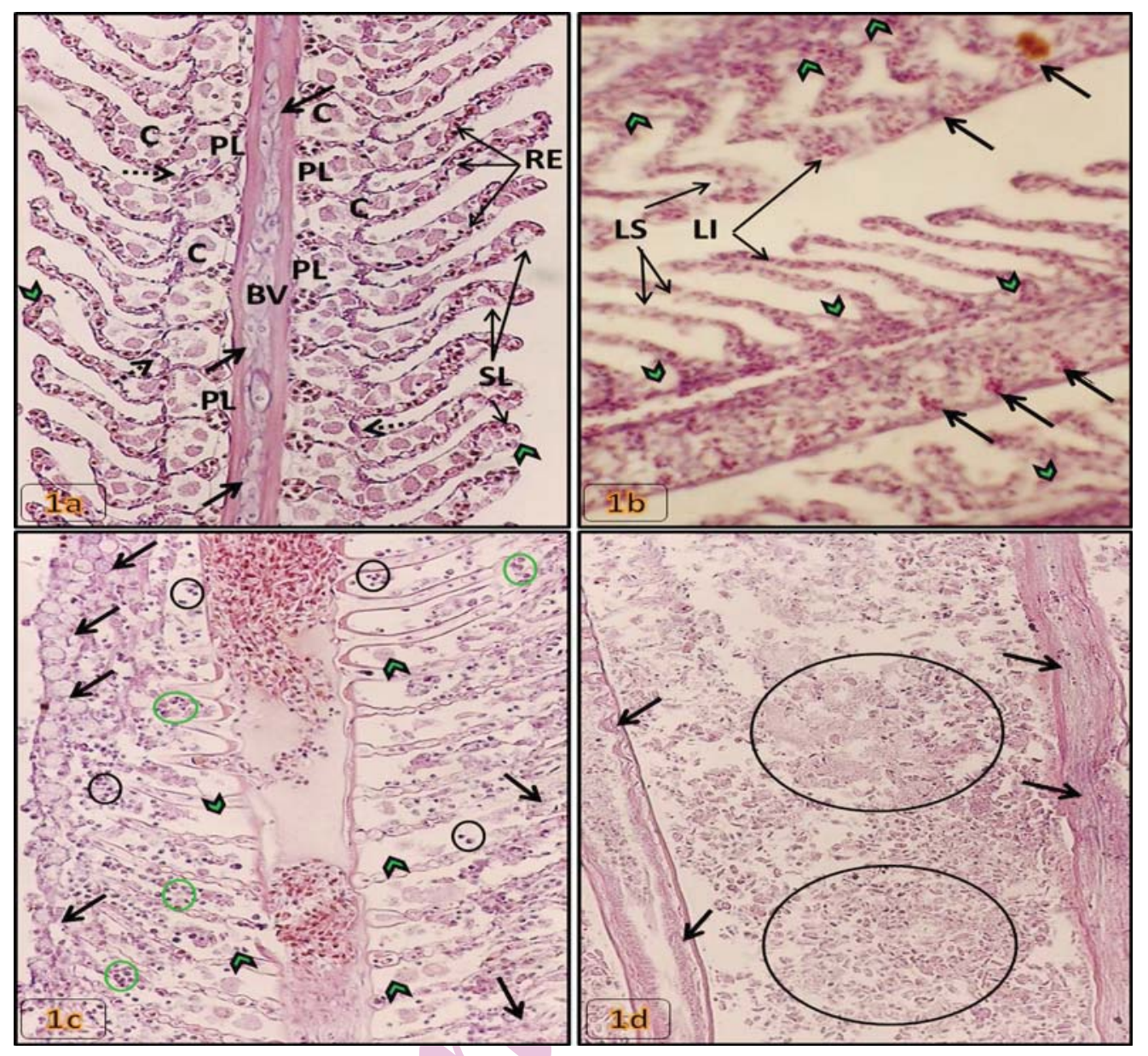

Fig. 1 (a-d) : Gill filaments of Luthjanus monostima (a) showing a primary lamellae (PL) with central blood vessel (BV) carrying on both sides secondary lamellae (SL), proliferation of chloride cells (C), Pillar cells (dashed arrows), mucous cells secretion (arrowheads), separation of respiratory epithelial (RE) with curved and expansion secondary lamellae and cartilaginous supporting axis (arrows) of primary lamella; (b) showing lamellar fusion and lysis (LS), lamellar blood sinusoids destroyed( arrow heads) leukocyte infiltration (LI) with accumulation of mucous cells secretions at fused surface (arrows); (c) showing part from the parasitic infected gill filament, lamellar necrosis, complete dissolution of blood sinusoids (arrowheads), mucous coagulation (arrows), chloride cells damage, heavy lymphocytic (black circles) and eosinophilic (green circles) infiltrations; (d) showing complete degeneration of gills lamellar with coagulative necrosis (circles) in parasitic infected gill tissue. Arrows indicate blood vessel fibroses (arrows). H\&E,1000x

fusion was observed side of the gill filaments as well as migration of epithelial cells of secondary lamellae towards the edge in a wave formation. The damaged pillar cells can result in an increased blood flow inside the lamellae, causing dilation of marginal channel. Athikesavan et at. (2006) reported that $\mathrm{Ni}$ enters the blood circulation of fish through gills and causes irritation to the gills during respiration and hypertrophy of gill filament and hyperplasia of epithelial surface. Also, Hadi and Alwan (2012) reported that cell proliferation with thickening of gill filament epithelium may lead to lamellar fusion. Sloughing of respiratory epithelia and filling of gaps between the fused surface and blood sinusoids of primary filaments with damaged and dissolved cells and infiltrated lymphocytic tissue. Also, added to that the damage of cartilaginous cells and its exposure to parasites causing damage and fibrosis of blood vessels (Fig.1 C and 1D). Similar studies on various fish species exposed to various heavy metals have revealed the concomitant ion- and osmoregulatory dysfunction effect on the diffusing capacity of gills and their ability to function in gaseous exchange resulting in accelerated cell necrosis and sloughing (Athikesavan et al., 2006). Secretion of mucus over gill curtails diffusion of oxygen which may ultimately reduce the oxygen uptake by fish (Ezemonye and Ogbomida, 2010). Destruction of gills blood vessels causes invasive infiltration of leucocytes and detrimental focal necrosis in gills (Mohamed, 2003). Mahmoud et al. (2014) reported that parasitic species are found in living organisms, their presence in their hosts is generally at equilibrium with the aquatic ecosystem, however natural or anthropogenic changes in the 
environment can change the state of balance of the parasite between the host and nature. Heavy metals increases the susceptibility of exposed fish to parasitic infection (El-Seify et al., 2011). As regard to intestinal alterations in the studied fish, majority of intestinal tissues were characterized by severe damage on all the four layers constituting the intestine gut including squamous epithelial cells layer, longitudinal and circular
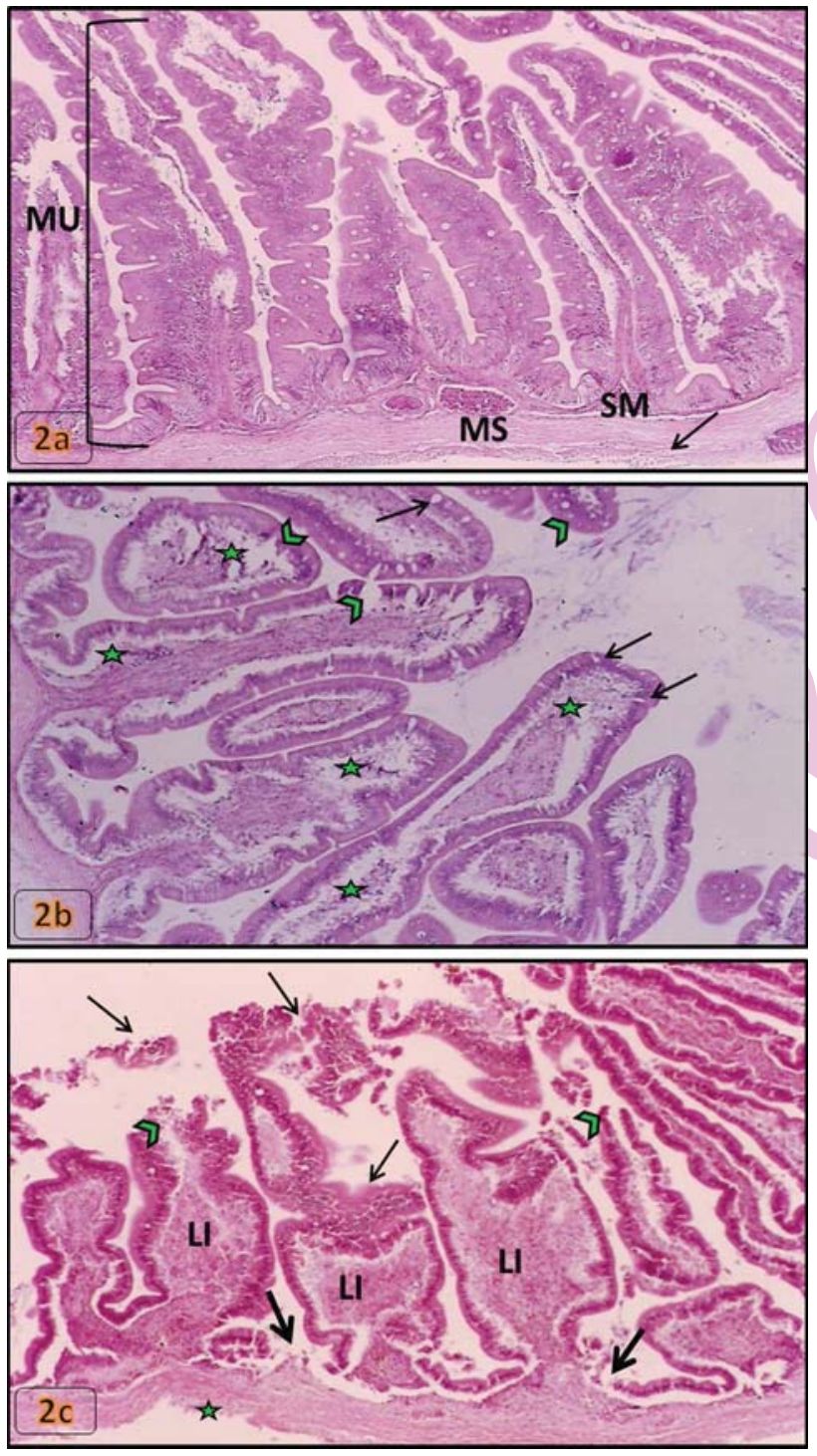

Fig. 2 (a-c) : Intestinal tissue of Luthjanus monostima (a) showing villi heterogeneity of mucosal (MU) layer, submucosal (SM) layer, muscularis (MS) layer and serosa (arrows); (b) showing goblet cells (arrows), vacuolar degeneration in mucosal epithelial cells (arrowheads) and heavy lymphocytic infiltration (*) in lamina propria; (c) sloughing and necrosis of mucosal epithelial cells (arrows), degeneration of the intestinal villi surface (arrow heads), lymphocytic infiltration (Li) and separation of mucosa (thick arrows) from submucosa and loose in longitudinal muscle layer $\left({ }^{*}\right) \cdot \mathrm{H} \& \mathrm{E}, 1000 \mathrm{x}$ muscular layer, submucosal layer and mucosal layer which contains columnar epithelial and goblet cells. The histological damage includes villi heterogeneity and regional increase in mucous cells, epithelial vacuolar degenerations and separation of mucosal epithelial layer of the intestinal villus with lymphocytic infiltration (Fig. 2A, B, C). Various evidence indicates that the toxic pollutants enters the digestive tract of fish via nutrition and water,

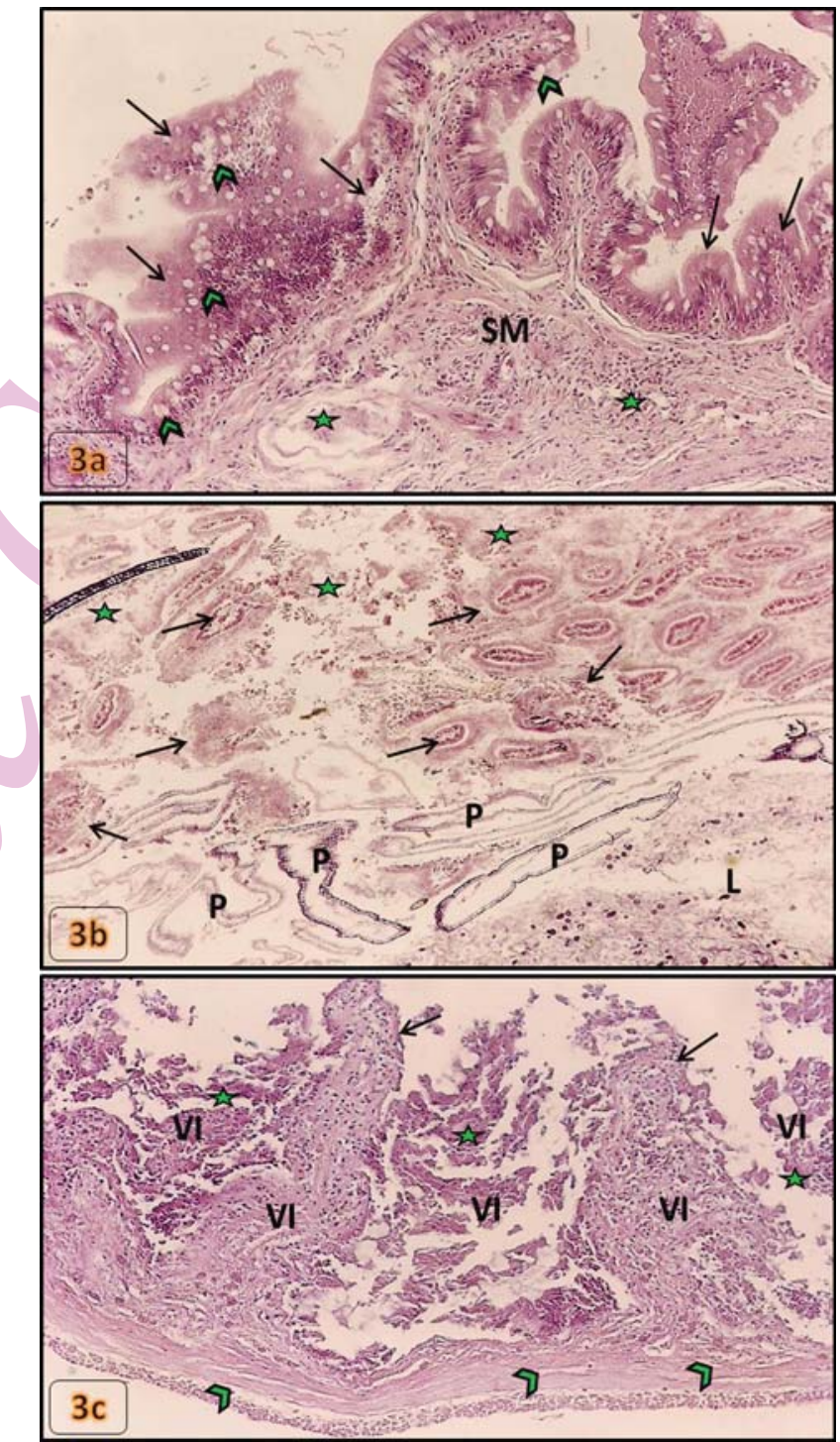

Fig. 3 (a-c) : Intestinal tissue of Luthjanus monostima (a) showing shortening of mucosa villi (arrow), vacuolar damage (heads arrow), sever hyperplasia of submucosa (SM) and inflammatory infiltrations (*); (b) showing intestinal villi (VI), damage and necrosis (arrows), disintegration of muscular layer $\left(^{*}\right)$ and dead tissue and parasites $(P)$ in lumen (L); (C) showing intestinal villi disintegration(*), villi fibrosis with epithelial cells sloughing (arrows) and split in longitudinal muscle layer (arrow heads). H\&E, 1000x 


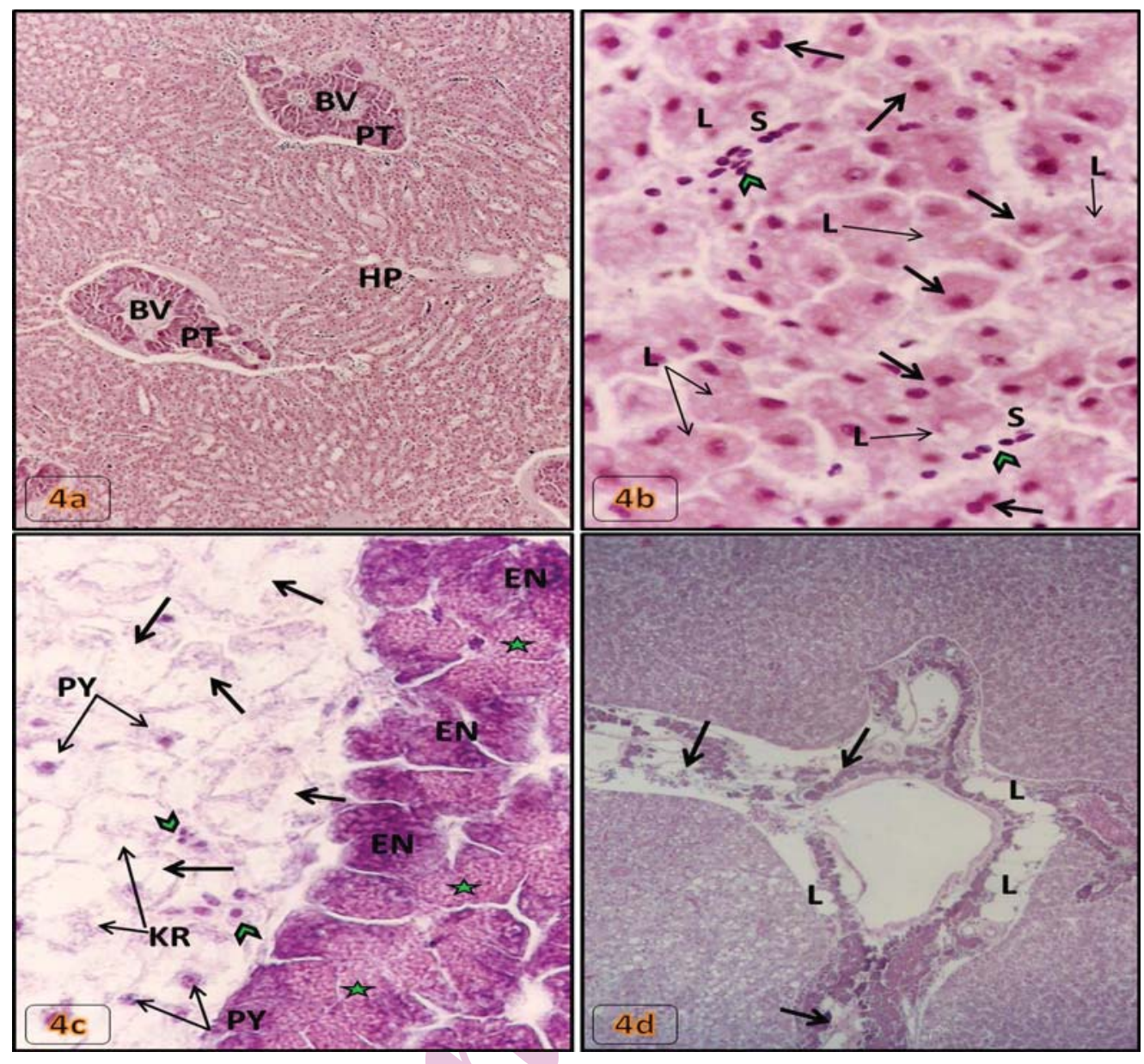

Fig. 4 (a-d) : Hepatic tissue of Luthjanus monostima (a) showing hepatic (HP) cells and pancreatic tissues (PT) surrounding blood vessels (BV); (b) showing polygonal hepatocytes with one or two central nuclei (arrows), lipid droplets (L), nucleated RBCs (arrow heads) in sinusoid (S). H\&E,1000x; (c) showing ballooning degeneration with deteriorated of cytoplasmic organelles (arrows), pyknotic (PY) and Karyolysis (KR) of nuclei, exocrine pancreatic tissue $\left(^{*}\right)$, endocrine pancreatic tissue (EN) and lymphocytic infiltration (heads arrow); (d) showing sever pancreatic tissue lysis (arrows) and lipid droplets (L) accumulation. H\&E, 400x

causing deterioration of structure and functions in the gut. Fig. $3 \mathrm{~A}$ shows hyperplasia of submucosal layer with cellular infiltration and complete dissolution and miniaturization of some villus or part of it as well as disintegration of muscular layer. Similarly, Younis et al. (2013) that disturbed longitudinal muscules and proliferation goblet cells with increased mucous secreation in addition to increased level of inflammatory cells and characteristic dilated blood vessels in Nile tilapia treated with cadmium, indicating a defense mechanism against severe pathological changes induced by $\mathrm{Cd}$ contamination. Fig. $3 \mathrm{D}$ shows the tissue sections of the intestinal cavity of some fish exhibited parasitic infestation.Such sections also showed evidence of mucosa sloughing, intestinal hemorrhage, cellular debris as well as inflammatory infiltration of eosinophils. Siquier and Ostrowski de Núnez (2009) reported that the parasitic loads in individual fish can often rise to such an extent that they occupy majority of total area of a specific organ. Iwanowicz, (2011) found that eosinophils cells are developed through snooping and are more abundant in inflamed regions. If the balance between the host and parasite is disturbed, the parasites attack the intestinal lining cells and digest them due to the presence of realized enzymes. As such, the internal mucosal layer is eroded gradually till the muscular layers and then reach to the circulatory system carrying the parasites to liver, lung and brain of causing deterioration in fish (Marcogliese, 2005). Fish are considered as carriers of pathogens and this is usually governed by the immune system (Knudsen et al., 2009; Al-Jahdali and Hassanine, 2010). Inflammatory intrusion of lymphocytic cells were evident on the mucosal layers (Fig. 3C). In agreement with these results, Kaoud et al. (2011) reported that the pathological findings in the intestine of Oreochromis niloticus treated with cadmium included atrophy of the muscules, degenerative and necrotic changes in the intestinal mucosa and 
submucosa with necrotic cells aggregated in the intestinal lumen, and edema and atrophy in submucosa. The histological examination of liver showed that hepatocytes were polygonal and contained spherical central with one or two nuclei grouped in bundles in the form of lobes around the central veins and pancreatic tissue, separated by blood sinusoids representing connected canals containing red blood cells (Fig. 4 A,D ). Despite the normal form of cells, droplets of fat which appeared empty in optical microscope pictures, pushed the nuclei towards the edge (Fig. $4 \mathrm{D}$ ), as well as dilation and congestion of blood sinusoids filled with red blood cells were observed. Most blood vessels were surrounded by eosinophilic cells with granulated cytoplasm (pancreatic exocrine portion) and noncentral nuclei, while the central portions appeared to be densly pigmented and such cells represent the endocrine pancreatic tissues (Fig. 4 A,C). In addition, the hepatocytes exhibited ballooning degeneration with severe loss of cytoplasmic density as well as nuclei pyknosis and karyolysis and the adhesion of plasma membrane. Furthermore, evidence of sinusoidal collapse was also noted in some samples as a result of cellular swelling and lymphocytic infiltration (Fig. 4C). Few tissue sections exhibited anomalies in the hepatic cells composition with large fat droplets inside the cells as well as sever necrotic and dissolution of pancreatic tissues with accumulation of fat droplets in some areas (Fig. 4D). The results of the present study is in agreement with the previous study of Athikesavan et al. (2006); Bin Dohaish et al. (2004) who reported that liver hepatocytes appeared swollen and vacuolized, acute inflammation including rupturing of hepatocytes, nuclei necrosis and degeneration of blood vessels in Siganus rivulatus fish exposed to $\mathrm{Fe}, \mathrm{Cu}, \mathrm{Cd}, \mathrm{Zn}$ and $\mathrm{Pb} \mathrm{Ni}$ and Hypophthalmichthys molitrix exposed to Ni. Younis et al. (2013); Ajani and Akpoilih, (2010) attributed these histological changes may be due to the direct toxic effect of pollutants on hepatocytes. Kaoud et al. (2011) observed hepatocyte degeneration, with nuclear pyknosis in the majority of cells of Oreochromis niloticus treated with cd. Similar to our findings Dezfuli et al. (2006) reported increased lipid droplets in response to $\mathrm{Cu}, \mathrm{Al}$ and $\mathrm{Pb}$ exposure due to decrease in protein synthesis and consequent non-utilization of lipids for lipid-protein conjugation. Metals can either increase or decrease hepatic enzyme activities and can lead to histopathological hepatic changes, depending on the metal type and concentration, fish species and duration of exposure (Hadi and Alwan, 2012).

It can be concluded that the water in the coastal waters of the study area is polluted with high levels of heavy metals such as $\mathrm{Fe}, \mathrm{Pb}$ and $\mathrm{Ni}$. Accumulation of these heavy metals effect the growth of Lutjanus monostigm fish causing histological variations. There remains a substantial need to understand the subcellular controls of metal accumulation and toxicity for different metals in different species of fishes as it form major source of protein all around the world. It is also useful to understand how we are contaminating our most natural resource of protein and thus appropriate guidelines and policies should be laid down to protect our water resources.

\section{References}

Ajani, E.K. and B.U.J. Akpoilih : Effect of chronic dietary copper exposure on histology of common carp (Cyprinus carpio). J. Ppl. Sci. Environ. Manage., 14, 39-45 (2010).

Ali, H.and A. Abdel-Satar : Studies of some heavy metals in water, sediment, fish and fish diet in some fish farms in El-Fayoum Province, Egypt. J. Aquat. Res., 31, 261-273 (2005).

Al-Jahdali, M.O. and R.M. El-S Hassanine : Ovarian abnormality in a pathological case caused by Myxidium sp. (Myxozoa, Myxosporea) in onespot snapper fish Lutjanus monostigma (Teleostei, Lutjanidae) from the Red Sea. Acta Parasitologica, 55,1-7 (2010).

Araneda, M., E.P Perez and L.E. Gasca : White shrimp Penaeus vannamei culture in freshwater at three densities: Condition state based on length and weight. Aquaculture, 283,13-18 (2008).

APHA: Standards methods for examination of water and waste water. Am. Pub. Health Ass., 22 ${ }^{\text {nd }}$ Edn., pp. 1360 (2012).

Athikesavan, S., S. Vincent, T. Ambrose and B. Velmurugan: Nickel induced histopathological changes in the different tissues of freshwater fish, Hypophthalmichthys molitrix (Valenciennes). J. Environ. Biol., 27, 391-395 (2006).

Bin-Dohaish, EL-G. A., EL-S. H. Abdelaziz and N. A. El-Ghazaly : The Toxic Effect of pollutants in the aquatic environment on the kidney and blood picture of Rabbit fish Siganus rivulatus (Forskal) from the Red Sea, Jeddah, Saudi Arabia. J. KAU. Mar. Sci., 15, 3-22 (2004).

Canli, M. and G. Atli. : The relationships between heavy metal ( $\mathrm{Cd}, \mathrm{Cr}$, $\mathrm{Cu}, \mathrm{Fe}, \mathrm{Pb}, \mathrm{Zn}$ ) levels and the size of six Mediterranean fish species. Environ. Poll., 121, 129-136 (2003).

Chandra, R. and N. Jhan : The analysis of length-weight relationship of Channa punctata with relative physico-chemical parameters. $J$. Exp Sci., 1, 4-5(2010).

Datta, S.N., V.N. Kaur, A. Dhawan and G. Jassal: Estimation of lengthweight relationship and condition factor of spotted snakehead Channa punctata (Bloch) under different feeding regimes. Springer Plus, 2, 436 -442 (2013).

De la Torre, F. R., A. Saliba and L. Ferrair : Biomarkers of native fish species (Cnesterodon decemaculatus) application to the water toxicity assessment of a per-urban polluted river of Argentina. Chemosphere, 59, 577-583 (2005).

Dezfuli, B. S., L. Giari, R. Konecny, P. Jaeger and M. Manera: Immunohistochemistry, ultrastructure and pathology of gills of Abramis brama from Lake Mondsee, Austria, infected with Ergasilus sieboldi (Copepoda). Disea. Aqu. Organi., 53, 257-262 (2003).

Dezfuli, B.S.,E. Simoni , L. Giari and M. Manera : Effects of experimental terbuthylazine exposure on the cells of Dicentrarchus labrax. Egypt Life Sci. J., 8, Chemosphere., 64,1684-1694 (2006).

EL-Ghazaly, N. A., EL-S.H. Abdelaziz and EL.G.A. Bin-Dohaish : Effect of pollutants in coastal water of Jeddah on the 1-histological structure of gills and intestine of the fish Siganus rivulatus Forskal, SaudiArabia. Egypt J. Aquat. Res., 321, 298-315(2006).

Elnabris, K. J., S.K. Muzyed and N. M. El-Ashgar : Heavy metal concentrations in some commercially important fishes and their contribution to heavy metals exposure in Palestinian people of Gaza Strip (Palestine). J. Associ Arab. Univer Basic. Appli Sci., 13, 44-51(2013).

El-Rayis, O.A. : Distribution of some heavy metals in sediments, water and different trophic levels from Jeddah coast, Red Sea. J.K.A.U., Mar. Sci., 3, 33-45 (1989).

El-Seify, M.A.,M.S. Zaki ,R.Y. Abdel- Desouky and H.A. Hossam, O.K.A. 
Hady and A.A. Abou Zaid, : Study on clinopathological and biochemical changes in some freshwater fishes Infected with external parasites and subjected to heavy metals pollution. Life Scie. J., 8, 401-405 (2011).

Ervnest, H. A.: Textbook of Modern Toxicology. $3^{\text {rd }}$ Edn., John Wiley and Sons, Hoboken, NJ, USA (2004).

Ezemonye, L. and T.E. Ogbomida: Histopathological effects of Gammalin 20 on African catfish Clarias gariepinus. Appli. Environ. Soil Sci., Article ID 138019, p.8 (2010).

FAO : The State of World Fisheries and Aquaculture (2010).

Farkas, N. and J. S. Specziár : Age- and size-specific patterns of heavy metals in the organs of freshwater fish Abramis brama $L$. populating a low-contaminated site. Water Res., 37, 959-964 (2003).

Hadi, A. A. and S.F. Alwan : Histopathological changes in gills, liver and kidney of fresh water fish, Tilapia zillii, exposed to aluminum. Int. J. Pharm. Life Sci., 3, 2071-2081(2012).

Iwanowicz, D.D.: Overview on the effects of parasites on fish health. United States Geological Survey, Leetown Science Center, Nati. Fish Heal. Res. Laboratory, 11649. Leetown Road, Kearneysville, WV 25430 (2011).

Kaoud, H. A.,M.M. Zaki, A.R. El-Dahshan, S. Saeid and H.Y. EL Zorba: Amelioration the toxic effects of cadmium-exposure in nile tilapia (Oreochromis niloticus) by using Lemnagibba L. Life Sci. J., 8,185195(2011).

Knudsen, R., P.A. Amundsen, M. Jobling and A. Klemetsen : Differences in pyloric caeca morphology between Arctic char Salvelinus alpines ecotypes : Adaptation to trophic specialization or parasiteinduced phenotypic modifications. J. Fish Biol., 73, 275-287 (2009).

Mahmoud, N.E., M. Badawy and M.M. Fahmy : Investigations on mass mortalities among Oreochromis niloticus at Mariotteya stream, Egypt : Parasitic infestation and environmental pollution impacts.
J. Aquac. Res. Develop., 5,1000219-1000310(2014).

Marcogliese, D. J. : Parasites of the superorganism: Are they indicators of ecosystem health. Int. J. Para., 35, 705-716 (2005).

Mohamed, F.A.: Histopathological studies on some organs of Oreochromis niloticus, Tilapia zillii and Synodontis schall from El-Salam Canal , Egypt. Egypt. J. Aquat. Biof. Fish, 7, 99-138 (2003).

Nussey, G., J.H.J. Van Vuren and H.H. du Preez : Bioaccumulation of chromium, manganese, nickel and lead in the tissues of the moggel, Labeo umbratus (Cyprinidae) from Witbank dam, Mpumalanga. Water SA, 26, 269-284 (2000).

Oscar, A., F. Laura and M. Jorge : Heavy metal concentration in litteral sediments from the Beagle Channel, Tierra del Fuego, Argentina. Enivron. Monit.Assess., 41, 219-231 (1996).

Peebuaa ,P., M. Kruatrachuea ,P.Pokethitiyooka and P.Kosiyachinda : Histological effects of contaminated sediments in MaeKlong River Tributaries, Thailand on Nile tilapia, Oreochromis niloticus. ScienceAsia, 32, 143-150 (2006).

Siquier, G.F. and M. Otrowski de Núňez : Ligophorus uruguayense sp. nov. (Monogenea, Ancyrocephalidae), a gill parasite from Mugil platanus (Mugilformes, Mugilidae) in Uruguay. Acta Parasitologica, 54, 95-102(2009).

Vosyliene, M. Z. and N. Kazlauskiene: Alterations in fish health status parameters after exposure to different stressors. Acta Zoologica Lituanica Hydrobiology, 9, 82-95 (1999).

Widianarko, B.,C.A. M. Van Gestel, R.A.Verweij and N. M. Van Straalen: Associations between trace metals in sediment, water and guppy, Poecilia reticulata (Peters), from urban streams of Semarang, Indonesia. Ecotox. Environ. Safe., 46, 101-107(2000).

Younis, S.M., A. A. Abdel-Warith, N.A. Al-Asgah, H. Ebaid and M. Mubarak: Histological changes in the iiver and intestine of Nile Tilapia, Oreochromis niloticus, exposed to sublethal concentrations of cadmium. Pakistan J. Zool., 45, 833-841 (2013). 